\title{
Correction
}

\section{Correction: Fujita et al., Neuronal Transgene Expression in Dominant-Negative SNARE Mice}

In the article "Neuronal Transgene Expression in Dominant-Negative SNARE Mice" by Takumi Fujita, Michael J. Chen, Baoman Li, Nathan A. Smith, Weiguo Peng, Wei Sun, Michael J. Toner, Benjamin T. Kress, Linhui Wang, Abdellatif Benraiss, Takahiro Takano, Su Wang, and Maiken Nedergaard, which appeared on pages 16594-16604 of the December 10, 2014 issue, the authors regret an error in Figure 3C, where the high-magnification insets of WT incorrectly appeared too dark. The figure was rechecked, and the inset images were replaced so that EGFP signal does not obscure, eliminate, or misrepresent information present in the original, including the background. This correction does not affect the conclusions and interpretations of the paper. Revised Figure 3 is listed below. 
A
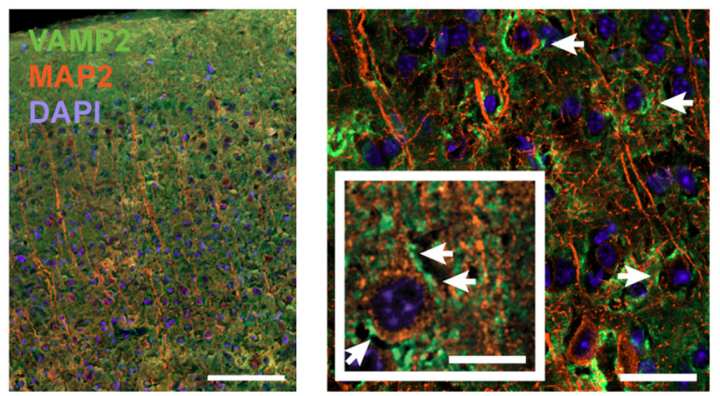

B

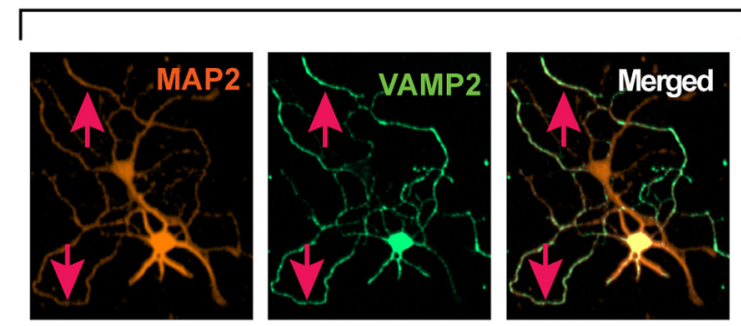

Astrocytes

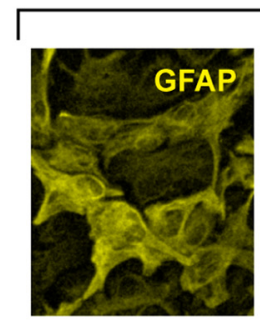

D

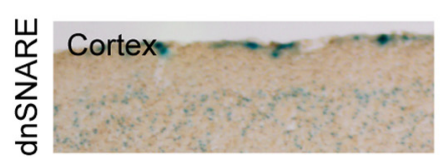

$\lessgtr$

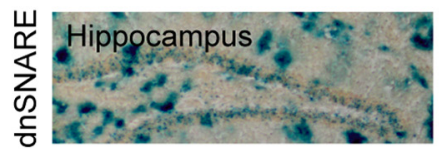

5

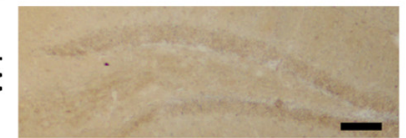

C InSNARE
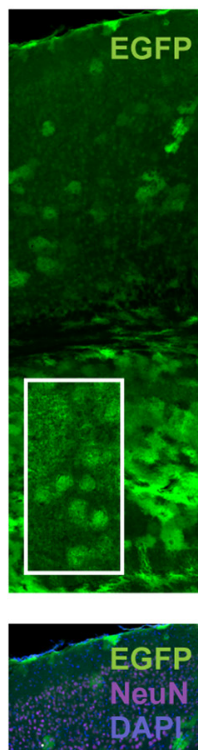

DAP

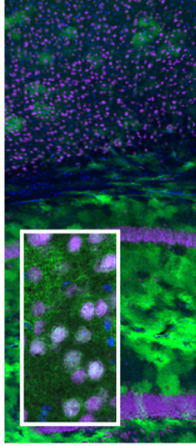

E

dnSNARE
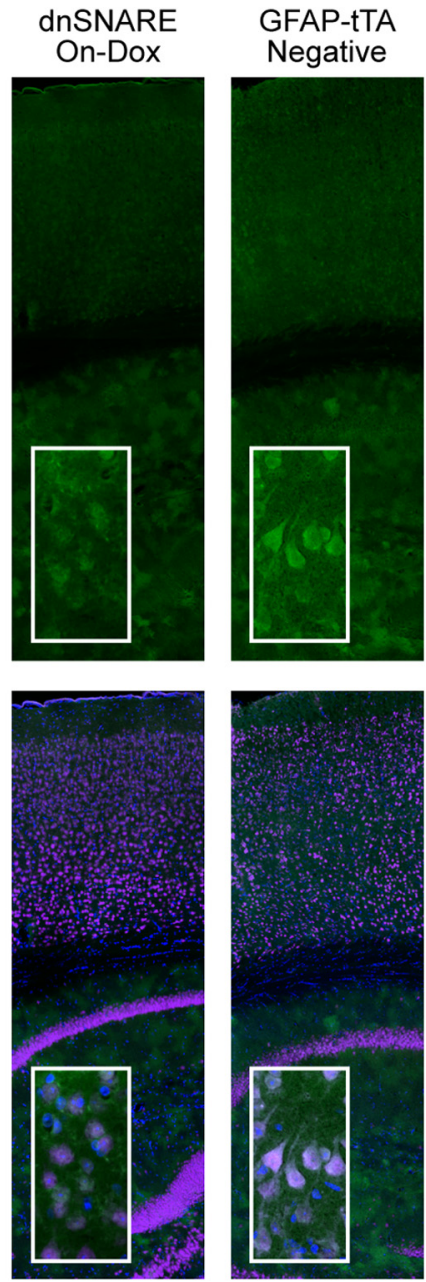

$\mathbf{F}$
GFAP-tTA
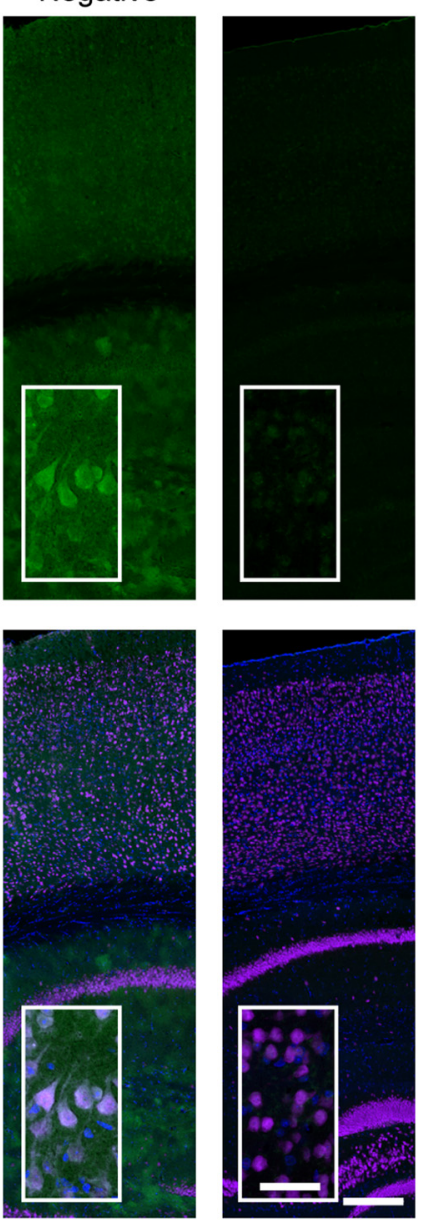

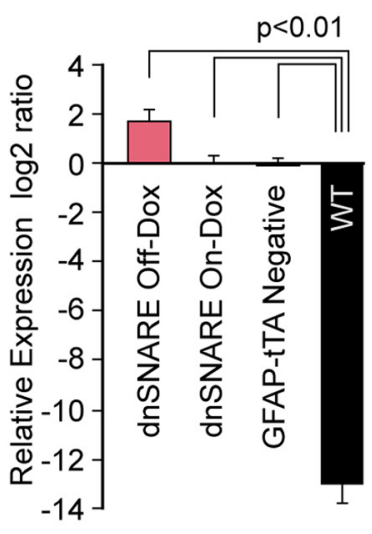

LacZ
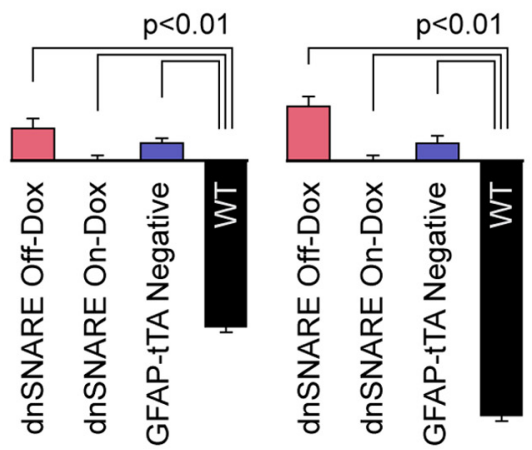

G

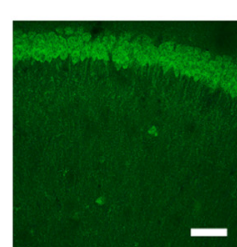

Figure 3.

DOI: 10.1523/JNEUROSCI.0803-16.2016 